UDC 343.213 .3

DOI 10.31733/2078-3566-2021-2-196-203

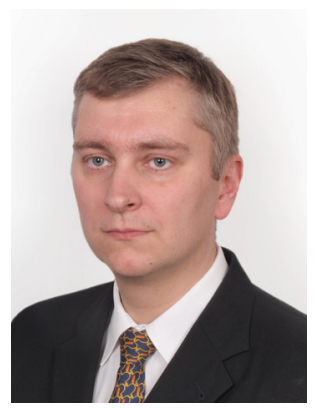

\author{
Adam WRÓBEL ${ }^{\odot}$ \\ Ph.D in Law \\ (Jan Dlugosz University in Czestochowa, Poland)
}

\title{
THE CONDITION OF DUAL CRIMINALITY IN THE PERSPECTIVE OF CRIMES COMMITTED ABROAD (FROM THE PERSPECTIVE OF POLISH CRIMINAL LAW)
}

Адам Врубель. Підстава подвійної криміналізації учинених за кордоном діянь (за кримінальним законодавством Польщі). Польський законодавець у ст. $111 \S 1$ Кримінального кодексу (далі - КК) визначає, що підставою відповідальності за діяння, вчинене за кордоном, $є$ визнання такого діяння злочином також згідно з чинним законодавством на місці його вчинення. Якщо ця умова не виконується, то польське кримінальне законодавство застосовується до громадянина Польщі та іноземця у випадках, коли діє принцип абсолютного застосування польського кримінального закону (ст. 112 КК) або принцип загальної репресії (ст. 113 КК). За змістом ст. 111 § 1 КК: а) „закон”, чинний на місці скоєння діяння (закордоном) - правовий акт, що містить абстрактні та загальні норми стосовно сфери прав та свобод особистості, публічно ним доведені тим, хто піклується про спільноту із посилається на причину (мотив), дану задля загального блага; б) діяння, визнане „злочином” також на місці його вчинення (закордоном), є конкретним злочином, ознаки якого в логічному сенсі входять до збірного поняття злочину за польським законодавством та відповідно до законодавства, що діє на місці вчинення (за кордоном). Необхідно враховувати обставини, що виключають протиправність, вину (провину); всі фактичні обставини мають бути враховані для того, щоб відповісти на питання: чи можливе, 3 точки зору польського кримінального законодавства, обвинувачення у вчиненні конкретного злочину щодо обвинуваченого у вчиненні забороненого діяння?

Ключові слова: кримінальне право Польщі; злочин, учинений закордоном; зарубіжна криміналізачія; подвійна криміналізація (за польським та зарубіжним кримінальним правом).

\section{Introduction}

Issues related to the question of the liability for a criminal act committed abroad are governed by the provisions of chapter XIII of the Polish Criminal Code, entitled: Responsibility for crimes committed abroad. The author undertakes to investigate one of the elements of the problem. Namely, he analyzes the condition of the dual criminality of an act committed abroad of Poland, examining the problem in the context of views expressed in doctrine and judicature. He focuses his reflections on the question of: a) an act recognized as a „crime” also abroad, and b), statute” in force at the place where the act was committed (abroad).

Article $111 \S 1$ of the Criminal Code typifies the condition of dual criminality. A condition of liability for an act committed abroad is the recognition of such an act as a crime also by the statute in force at the place of its committing (lex loci delicti commissi). As the Supreme Court rightly observes, failure to fulfill the condition specified in art. $111 \S 1$ C.C, that's mean the condition of recognition as a crime committed abroad also by the statute in force at the place where it was committed, constitutes an obstacle to the conduct proceedings in the case of criminal responsibility in a Polish court, even if the act would filled signs of crime specified in the Polish Criminal Code ${ }^{1}$. In the context of art. $111 \S 1$ C.C. it is about a crime in the sense and scope to which it was defined in Polish law. Simplifying, it is about a human act $^{2}$, prohibited by the statute under penalty (felony or misdemeanor $)^{3}$, unlawful ${ }^{4}$, culpable ${ }^{5}$, harmful to a degree higher than the negligible ${ }^{6}$.

${ }^{1}$ Thesis of the judgement of the Court of Appeal in Gdansk of December 18, 2014, sign. II AKa 418/14, LEX No. 1953275; similarly in: thesis of the judgement of the Supreme Court of March 17, 2011, sign. III KK 352/10, LEX No. 794160.

(C) Adam WRÓBEL, 2021

ORCID iD: https://orcid.org/0000-0002-9315-0213

a.wrobel@ujd.edu.pl 


\section{Exclusion of dual criminality}

The condition of art. $111 \S 1$ C.C. does not apply to a Polish public functionary who has committed crime abroad while serving there, in connection with the performance of his duties, or to a person who committed a crime in a place that is not subject to any state authority. A

${ }^{2}$ Under Polish criminal law, only a natural person can be criminally liable. Under the rules specified in the Polish Criminal Code, the person who commits the prohibited act after the age of 17 years incurs criminal liability. Minor who, after the age of 15, committed a prohibited act specified in art. 134 (a crime of - simplifying - assassination of the President of the Republic of Poland); art. 148 (crime of - simplifying murder, excluding murder in affect) $\S 1,2$ or 3; art. 156 (crime of - simplifying - intentional serious damage of health and intentional serious damage of health which results is humans death) $\S 1$ or 3 ; art. 163 (crime of - simplifying - intentionally bringing a commonly dangerous acci-dent) $\S 1$ or 3; art. 166 (crime of simplifying - seizure of a ship or aircraft); art. 173 (crime of - simplifying - intention-ally causing a catastrophe in communication and intentionally causing a catastrophe in communication with the con-sequence in the form of: a danger of man's death or grievous bodily harm of many people, or danger for property in large sizes) $\S 1$ or 3; art. 197 (crime of - simplifying - committing a rape together with another person, against a minor under 15 , against a ascendant, descendant, adopted, adopter, brother or sister and rape with especial cruelty) $\S 3$ or 4; art. 223 (crime of - simplifying - active assault on a public functionary which results a serious damage of health of a public functionary or a person established to help him) $\S 2$; art. 252 (crime of - simplifying - taking a hostage) $\S 1$ or 2 ; art. 280 (crime of - simplifying - robbery), may be responsible according the rules specified in Polish Criminal Code, if the circumstances of the case and the degree of development of the perpetrator, its characteristics and personal condi-tions speak for it, and in particular, if the previous educational or corrective measures proved to be ineffective (art. 10 \& C.C.).

${ }^{3}$ It is about the statute as a source of laws commonly in force in Poland. For example, the Criminal Code law or other statutes contain criminal laws, such as aviation law, geological and mining law, pharmaceutical law. In the Crim-inal Code, the Polish legislator outlines rules of the qualification of crimes, indicating that: a) the crime is a felony or a misdemeanor (art. $7 \S 1$ of C.C.), b) the felony is a prohibited act, punishable by imprisonment for a period not shorter than 3 years or stricter penalty (art. $7 \S 2$ C.C.), c) a misdemeanor is a prohibited act, punishable by a fine of over 30 daily rates or above PLN 5000, a penalty for the restriction of liberty exceeding one month or imprisonment exceeding one month (art. 7 § 3 C.C.).

${ }^{4}$ Unlawful that's mean in this case illegal.

${ }^{5}$ Culpability is associated with the so-called allegation of the act; it occurs if it is possible to allegated the perpe-trator the committing of the act. The limits of allegation are specified in the statute, establishing the conditions of a culpability and pointing to circumstances which exclude culpability (Lech Gardocki, Prawo karne [Criminal law] (War-szawa: C.H. Beck, 2017) p. 92 and 93. The perpetrator of a prohibited act does not commit a crime if the culpability can not be attributed to him during the act (article $1 \S 3$ C.C.). Culpability is connected with the subjective side of the act; with intentionality and unintentionality. A prohibited (forbidden) act is committed intentionally, if the perpetrator intends to commit it, that is, he wants to commit it or anticipate the possibility of committing it agrees on it (art. 9 § 1 C.C.). An prohibited act is committed unintentionally, if the perpetrator does not intent to commit it, but commits it, as a result of failure to observe the caution required in the specific-concrete circumstances, despite that he anticipated the possibility of committing this act, or it could have been anticipated (art. $9 \S 2$ C.C.). The perpetrator bears more severe responsibility, which the law makes dependent on a specific consequence of a prohibited act, if the consequence was anticipated or could have been anticipated (art. 9 \& 3 C.C.). In the perspective of culpability issue, should also be noted circumstances that exclude culpability. These circumstances include, among others: a) insanity of the perpetrator (does not commit a crime who, due to mental illness, mental retardation or other disruption of mental activities, could not recognize the meaning of the act or could not guide his behaviour during the act [art. 31 \& 1 C.C.] if, at the time of committing a crime, the ability to recognize the meaning of the act or the ability of guiding behaviour, was significantly reduced, the court may apply extraordinary mitigation of punishment [art. $31 \S 2$ C.C.]; the provisions of $\S 1$ and 2 of art. 31 C.C. does not apply, when the perpetrator got himself into a state of intoxication or intoxication that results the exclusion or reduction of sanity, which he anticipated or could have anticipated [art. 31 § 3 C.C.]); b) error (does not commit a crime, who remains in justified error as to the circumstance constituting the mark of a prohibited act [art. $28 \& 1$ C.C.]; is liable under a provision providing for a lighter responsibility for the perpetrator who commits the act in a justified mistaken belief that there is a circumstance constituting the mark of a prohibited act, on which such a milder responsibility depends [art. $28 \S 2$ C.C.]; does not commit a crime, who commits a prohibited act in a justified mistak-en belief that there is a circumstance which excludes unlawfulness or culpability; if the perpetrator's error is unjustified, the court may apply 
public func-tionary is - in accordance with art. $115 \S 13$ C.C. - President of the Republic of Poland; deputy of the parliament, senator of the parliament, councilor; Member of the European Parliament; judge, as-sessor (juror), public prosecutor, functionary of the financial body of the preparatory proceedings or functionary of the superior body over the financial body of preparatory proceedings, notary, bailiff, probation officer, trustee, court supervisor and administrator, a person adjudicating in disciplinary bodies acting on the basis of the statute; a person who is an employee of the government administra-tion, another state body or local government, unless he performs only service activities, and another person to the extent that he is entitled to issue administrative decisions; a person who is an employ-ee of a state control body or a local government control body, unless he performs only service activi-ties; a person holding a managerial position in another state institution; a functionary of the body appointed to protect public safety or a functionary of the prison service; a person performing active military service, except for territorial military service performed disposable; an employee of an inter-national criminal court, unless he performs only service activities.

It must be noted that the condition of dual criminality specified in art. $111 \S 1$ C.C. does not always apply. This is indicated in art. 112 C.C., which concerns the principle of unconditional application of the Polish penal law (statute). That provision states, that regardless of the provisions in force at the place where the prohibited (forbidden) act was committed, the Polish penal law (statute) applies to a Polish citizen and a foreigner, in the event of committing: a) crime against the internal or exter-nal security of the Republic of Poland (art. 112 pkt 1 C.C.); b) crime against Polish offices (authori-ties) or public functionaries and the crime of extorting authentication of a falsehood from a Polish public functionary or another person authorized under the Polish law to issue a document (art. 112 pkt 2 C.C.); c) crime against significant Polish economic interests (art. 112 pkt 3 C.C.); d) crime of false testimony, submission of a false statement, opinion or translation, the use of a document stat-ing the identity of another person, certifying untruth or false - towards the Polish office (art. 112 pkt 4 C.C. $)^{7}$, e) the crime from which a property benefit in the territory of the Republic of Poland was achieved, even indirectly (art. 112 pkt 5 C.C.). Likewise, in the context of the principle of uni-versal repression, it is not necessary to fulfill the condition of art. $111 \S 1$ C.C.; that is to say, re-gardless of the regulations in force at the place where the crime was committed, the Polish penal law (statute) applies to a Polish citizen and a foreigner, who was not decided to be issued, if the crime would be committed abroad by polish citizen or foreigner - crime to which the Republic of Poland is required to prosecute under an international agreement, or a crime specified in the Rome Statute of the International Criminal Court, drawn up in Rome on July 17, 1998 (Journal of Laws of 2003, item 708) (art. 113 C.C.). Therefore, it is rightly pointed out in the thesis of the judgment of the Court of Appeal in Krakow, that if the condition of dual criminality - specified in art. $111 \S 1$ C.C. - is not fulfilled, prosecution of a Polish citizen or a foreigner for a prohibited act committed abroad of Polish state, it is possible only in the event of special conditions referred to in art. 112 C.C. or art. 113 C.C. are fulfilled ${ }^{8}$.

extraordinary mitigation of punishment [art. 29 C.C.]); c) unawareness of unlawfulness (does not commit a crime, who commits a prohibited act in the justified unconsciousness of his unlawfulness; if the perpetrator's error is unjustified, the court may apply extraordinary mitigation of punishment [art. 30 C.C.]); d) execution of an or-der (a soldier who commits a prohibited act being an execution of order is not committing a crime, unless he intention-ally commits a crime by following the order [art. 318 C.C.]).

${ }^{6} \mathrm{~A}$ prohibited act is not a crime, whose social harmfulness is negligible (art. $1 \S 2$ C.C.). In assessing the degree of social harmfulness of an act, the court takes into account the type and nature of the infringed good, the extent of the caused damage or the treated damage, the manner and circumstances of committing an act, the importance of duties infringed by the perpetrator, as well as the form of intention, motivation of the perpetrator, the type of infringed prudence rules and the degree of theirs infringement (art. $115 \S 2$ C.C.). Determining, that a specific act is socially harmful in a negligible degree, it does not diminish the value of the protected good, but it is an expression of the as-sessment, that this good was infringed in a slight degree; the judgement of the Supreme Court of September 4, 2002, sign. V KKN 199/01, LEX No. 56829.

${ }^{7}$ As the Supreme Court observes, in the case of a crime of false testimony, that has been submitted abroad to other organ than Polish, the perpetrator may be liable before a Polish court, but on condition, that the act is a crime at the place of committing (such rule was expressed directly in art. $111 \S 1$ C.C.). In the perspective of that regulation is undoubtful, that is no reason to recognize, that the act committed abroad, 


\section{Foreign crime - crime committed abroad}

Concerning the condition of dual criminality, the legislator stated, that the condition of liability for an act committed abroad is the recognition of such act as a crime also by the statute in force at the place of its committing (art. $111 \S 1$ C.C. $)^{9}$. In accordance to this condition, the Polish penal statute applies on the basis of the ${ }^{10}$ : C.C. $)^{11}$;

a) personal principle; in relation to a Polish citizen who committed a crime abroad (art. 109

b) relative protective principle; in relation to: a foreigner who committed a prohibited act abroad against the interests of: the Republic of Poland, a Polish citizen, a Polish legal person or a Polish organizational unit without legal personality, and; a foreigner who committed abroad a crime with a terrorist nature $(110 \S 1$ C.C.);

c) principle of replacement liability; in the event of a foreigner committing abroad a prohibited act other than a prohibited act directed against the interests of the Republic of Poland, a Polish citi-zen, a Polish legal person or a Polish organizational unit without legal personality, and a foreign-er who committed abroad a crime with a terrorist nature; if the act is prohibited by the polish penal statute, punishable by a penalty exceeding 2 years of imprisonment, and the perpetrator resides in the territory of the Republic of Poland and it was not decided to extradite him (art. 110 § 2 C.C.)

The legislator defines in art. 111 C.C., that the condition of liability for an act committed abroad is the recognition of such an act ,as a crime" there (abroad, what means in this case - in the place of committing $)^{12}$. In that context, different views are expressed - convergent or opposite - in-dicating that: a) the condition, that the act would be a crime not only in Poland but also in a place where it was committed, does not mean that it must have the formal status of crime. It may be an act with a different name or a different rank, just to be a prohibited act under penalty, conceptually corresponding to Polish felony or misdemeanors ${ }^{13}$;

consisting in giving false testimony to other organ than Polish, is not a crime; the judgement of Supreme Court of March 29, 2011, sign. III KK 365/10; LEX No. 852228.

${ }^{8}$ Thesis to the judgement of Court of Appeal in Krakow of April 27, 2016, sign. II AKa 45/16, LEX No. 2268989.

${ }^{9}$ What is also emphasized in the thesis of the judgement of Court of Appeal in Krakow of April 27, 2016, sign. II AKa 45/16, LEX No. 2268989.

${ }^{10}$ What is rightly pointed out in the doctrine; See K. Wiak (in:) A. Grześkowiak, K. Wiak (red.), Kodeks karny. Komentarz [Criminal Code. Commentary] (Warszawa: C.H. Beck, 2019), p. 726.

${ }^{11}$ As the Court of Appeal in Gdansk maintains: the application of the solution provided for in art. 111 C.C., de-pends on the determination, that the crime was committed by a Polish citizen abroad; thesis to the judgement of Su-preme Court in Gdansk of November 20, 2014, sign. II AKa 366/14, LEX No. 1799197. The judicature also emphasiz-es, that the application of the solution provided for in art. 111 C.C. depends on the determination, that the crime was committed by a Polish citizen abroad. In the case of a crime committed by a Polish citizen in Poland, there is no need to determine, whether a specific behavior is also a crime outside of the borders of the Polish state, even then, if further actions taken by the perpetrator, having no longer relevant to the accepted legal qualification, were made by another person, but already outside the territory of Poland; thesis to the judgement of the Court of Appeal in Lodz of January 24, 2002, sign. II AKa 240/01, LEX No. 103071.

${ }^{12}$ As for example, Supreme Court points out: in the case of committing a crime of false testimony, that has been submitted abroad to an organ other than Polish, the perpetrator may be liable before a Polish court, but on condi-tion that his act is a crime in the place where it was committed (such rule was directly expressed in art. $111 \S 1$ C.C.). In the context of that regulation it is clear, that there is no basis for recognition, that the act - of false testimony that has been submitted abroad to an organ other than Polish - committed abroad, is not a crime. The perpetrator of such crime, can be held to responsibility in Poland for false testimony, if it is a crime in the state in which it was submitted; judg-ment of the Supreme Court of March 29, 2011, sign. III KK 365/10, LEX No. 852228. As has been noted - for exam-ple - for the Court of Appeal in Lodz: application of the solution provided for in art. 111 C.C. depends on the determi-nation, that the crime was committed by a Polish citizen abroad. In the case of a crime committed by a Polish citizen in Poland, there is no need to determine, whether the specific behavior is also a crime outside the borders of the Polish state, even if further activities of the perpetrator, irrelevant (yet) to the accepted legal qualification, have been done by other person, but already outside Polish territory; thesis to the judgement of Court of Appeal in Lodz of January 24, 2002, sign. II AKa 240/01, LEX No. 103071. 
b) the act committed by the perpetrator abroad must be penalized as a crime both in the Polish pe-nal statute and the law in force at the place and time of its commission (lex loci), this act can be counted among the behaviors, corresponding to types to the concepts of felony or misdemeanor that have been accepted in the Polish legal system; the requirement of dual criminality can therefore also be fulfilled in the situation, if the act at the place where it was committed is an offense. It does not matter if the crime covers offens in accordance with the statute in force at the place where the act was committed ${ }^{14}$;

c) it is about a dual criminality understood in concreto, that is a liability which consists not only in determining that a specific act is prohibited as a crime in the place of committing, but also whether the perpetrator could be criminally liable there. In this case, it is not just about to declare the existence of a specific type of prohibited act, but also to assess possible circumstances which exclude unlawfulness, culpability or even procedural aspects - even if there is no complaint in the case of private complaint crimes or the absence of a request for prosecution in the case of application crimes ${ }^{15}$; moreover should be taken into account, among others such a cir-cumstance as the limitation period of an act according to the law of a foreign state ;

The legislator defines in art. 111 C.C., that the condition of liability for an act committed abroad is the recognition of such an act ,as a crime" there (abroad, what means in this case - in the place of committing $)^{12}$. In that context, different views are expressed - convergent or opposite - indicating that: a) the condition, that the act would be a crime not only in Poland but also in a place where it was committed, does not mean that it must have the formal status of crime. It may be an act with a different name or a different rank, just to be a prohibited act under penalty, conceptually corresponding to Polish felony or misdemeanors ;

b) the act committed by the perpetrator abroad must be penalized as a crime both in the Polish pe-nal statute and the law in force at the place and time of its commission (lex loci), this act can be counted among the behaviors, corresponding to types to the concepts of felony or misdemeanor that have been accepted in the Polish legal system; the requirement of dual criminality can therefore also be fulfilled in the situation, if the act at the place where it was committed is an offense. It does not matter if the crime covers offens in accordance with the statute in force at the place where the act was committed ;

c) it is about a dual criminality understood in concreto, that is a liability which consists not only in determining that a specific act is prohibited as a crime in the place of committing, but also whether the perpetrator could be criminally liable there. In this case, it is not just about to declare the existence of a specific type of prohibited act, but also to assess possible circumstances which exclude unlawfulness, culpability or even procedural aspects - even if there is no com-

${ }^{13}$ V. Konarska-Wrzosek (in:) V. Konarska-Wrzosek (red.), Kodeks karny. Komentarz [Criminal Code. Commen-tary], (Wolters Kluwer Polska, 2018) [last viewed: May 03, 2019], https://sip.lex.pl/\#/ commentary/587715742/571001, commentary to the art. 111, thesis 1 . V. Konarska-Wrzosek indi-cate in this case on the decision of the Supreme Court of December 16, 1994, sign. I KZP 29/94, LEX No. 20710. In this judgement, the Supreme Court - admittedly referring to art. 113 of the Criminal Code of 1969 - pointing out, that it is obvious, that a comparative study of Polish legislation and legislation in force at the place where a Polish citizen commits a crime abroad, should be conducted with particular insight, because in comparable legal systems may be significant differences. The result of such study, must be to determine that - independently of any differences, regard-ing the legal classification of prohibited acts under penalty, as well as the systems of envisaged penal measures and types of statutory threat of sanction - the analyzed act may be included to such behavioral categories, that genuinely correspond to the accepted in the Polish legal system, the concepts of misdemeanor or felony.

${ }^{14}$ Ibid., thesis 4 . A. Sakowicz adds, that it seems, that the requirement of dual criminality will be fulfilled, if an act in the place of its committing is an offense. This thesis is correct, as long as according to the law of the place of committing an act (lex loci), for crimes are considered not only felonies, misdemeanors, but also offenses (like for ex-ample in France or in Italy), A. Sakowicz (in:) M. Królikowski, R. Zawłocki (red.), Kodeks karny. Część ogólna. Komen-tarz. Art. 1-116 [Criminal Code. General section. Commentary. Art. 1-116] (Warszawa: C.H. Beck, 2017), p. 1331. In the doctrine, it is also indicated - generally - that the condition of art. $111 \S 1$ C.C. is not fulfilled in the case, when such act is an offense abroad; R.A. Stefański, Prawo karne materialne. Część szczególna [Material criminal law. Special section] (Warszawa: Centrum Doradztwa i Informacji Difin sp. z o.o., 2008), p. 76.

${ }^{15}$ M. Kulik (in:) M. Mozgawa (red.), Kodeks karny. Komentarz aktualizowany [Criminal Code. Updated com-mentary], (System Informacji Prawnej LEX, 2018) [last viewed May 9, 2019], https://sip.lex.pl/\#/ commentary/587736937/578774, commentary to the art. 111, thesis 1 . Similarly A. Sakowicz, op. cit., p. 1330.

${ }^{16}$ Thesis to the judgement of District Court in Bialystok of February 6, 2014, sign. VIII Ka 790/13, 
plaint in the case of private complaint crimes or the absence of a request for prosecution in the case of application crimes ; moreover should be taken into account, among others such a circumstance as the limitation period of an act according to the law of a foreign state ${ }^{16}$;

d) ailure to fulfil referred in art. $111 \S 1$ C.C. condition of recognition as a crime, of an act committed abroad, also by the law in force at the place where it was committed, constitutes an obstacle to conduct of criminal proceedings in the case of criminal liability before a Polish court, even if the act would filled the signs of crime foreseen in the Polish Criminal code ${ }^{17}$,

e) it is not sufficient to recognize this act by foreign law as a delict of administrative law (Resolution of the Supreme Court of December 16, 1994, sign. I KZP 29/94, OSNKW 1995, No. 1-2, pos. 4). Doubts may also arise as a liability for the offense, although it seems, that it is possible to assume, that in the indicated provision is about an offense and in any case should be considered the nature of this offense in a specific legal order ${ }^{18}$,

f) the fulfillment of the condition of dual criminality is not dependent on that, whether an act in concreto is punishable or not, it is important to consider it as a crime; if, therefore, the criminali-ty of an act is eliminated due to the exclusion of criminality or the exclusion of penalty accord-ing to the law in force at the place where it was committed, the condition of dual criminality is fulfilled (art. $111 \S 1$ C.C. refers to "such" act, not to "this" act). In such situation, a modifica-tion of the scope of application of this condition may come into play; it consists in the fact, that the court may take into account the differences between the two statuses subjected to evalua-tion, in favor of the perpetrator (art. $111 \S 2$ C.C.). If the act at the place where it was commit-ted is classified as a crime (ordinary crime), whereas in the Polish legal order, it is qualified as a fiscal crime, fiscal offense or offens (ordinary offens), the condition of dual criminality from art. $111 \S 1$ C.C. is not fulfilled ${ }^{19}$,

g) the question of the criminality of an act committed abroad is assessed in concreto, which means that it is not enough, that this act would exhaust the signs of crime under foreign law. It must also be a culpable and punishable act under that law. It is therefore necessary to establish that in both legal systems can be constructed a norm prohibiting certain behavior. It is not important to classify a specific act as a felony or misdemeanor, but rather it is crucial to determine that a spe-cific act constitutes in a concrete legal order a basis for bringing the perpetrator to criminal re-sponsibility ${ }^{20}$;

h) the condition of liability from art. $111 \S 1$ C.C. is not fulfilled, when the perpetrator committed an act recognized as an offense in the place (abroad) where it was perpetrated. It is obvious that the legal systems of individual countries may differ and differ in this scope. Some acts criminalized in Poland as crimes may be considered as offenses in another state. Thus, in the case of foreign law clearly dividing acts prohibited by" penalties for crimes and offenses, the analyzed condition will not be fulfilled in the event of a offense if such act is subjecting to the jurisdiction of administrative authorities and in the case of submission of such act to the competence of courts. In the case of foreign law not recognizing separate of crimes category of prohibited acts, prohibited under penalty, the analyzed condition would also be fulfilled in the case of an act considered as an crime, but within the internal categorization of crimes considered as an acts of an abstractly low social harmfulness. The subject condition would be fulfilled, for instance in the case of an act so-called a simplified crime (summary offense) in English criminal law ${ }^{21}$;

i) it is obvious that a comparative research of Polish legislation and legislation in force at the place, where a Polish citizen commits a „crime” abroad, should be carried out with particular insight, because in comparable legal systems may exist significant differences. However, the result of such research, must be to determine that - regardless of any differences concerning the legal classification of punishable prohibited acts, as well as the systems of envisaged penal measures and types of statutory threat of sanction - the analysed act may be included in such categories of behavior, which as to the type corresponds to the accepted in the Polish legal

LEX No. 1893823; similarly K. Wiak, op. cit., p. 727.

${ }^{17}$ Thesis to the judgement of Supreme Court of March 17, 2011, sign. III KK 352/10, LEX No. 794160.

${ }^{18}$ P.Czarnecki,P.Hofmański(in:)M.Filar(red.)Kodeks karny.Komentarz[CriminalCode.Commentary]

(Wolters Kluwer, 2016) [last viewed: May 9, 2019], https://sip.lex.pl/\#/commentary/587611083/503322, commentary to the art. 111, thesis 2 .

${ }^{19}$ G. Łabuda (in:) J. Giezek (red.), Kodeks karny. Część ogólna. Komentarz [Criminal Code. General section. Commentary] (Wolters Kluwer Polska, 2012) [last viewed: May 15, 2019], https://sip.lex.pl/\#/ commentary/587230746/125636, commentary to the art. 111, thesis 2.

${ }^{20}$ P. Czarnecki, P. Hofmański, op. cit., commentary to the art. 111, thesis 3.

${ }^{21}$ K. Banasik, „Warunek podwójnej kryminalizacji (art. $111 \S 1$ k.k.)” [Dual criminality condition (art. 111 § 1 C.C.)], Przegląd Sądowy, No. 9/2016 [last viewed: May 16, 2019] https://sip.lex.pl/\#/ publication/151294858.

${ }^{22}$ Decision of Supreme Court of December 16, 1994, sign. I KZP 29/94, LEX No. 20710. 
system, con-cepts of misdemeanor or felony ${ }^{22}$

j) the condition of dual criminality must be interpreted in abstracto. Circumstances excluding the criminality of an act (insanity, necessary defense, etc.) and its prosecution must be taken into account by the Polish court, at the stage of determining about criminal liability, but only from the perspective of Polish law, based on the provisions of the Polish criminal statute; according to the author of this view - this is supported by the fact that there is no precise, statutory nota-tion that limitation period in the state of committing act is a negative obstacle to conducting criminal proceedings in Poland and therefore it can not be inferred, that the intention of the leg-islator was to take into account this circumstance; moreover, a warrant of abstractly understand-ing the condition of dual criminality beside the interpretation of art. $111 \S 1$ C.C. is apparent from a linguistic interpretation of the provision, in relation to the interpretation of the provision of art. $604 \S 1$ point 2 Code of Criminal Procedure. That interpretation leads to the conclusion that, in first normalization it is not about such a strict understanding of the condition of dual criminality, as in the case of extradition. If that were so, the legislator would harmonize the wording of both provisions - in particular that the Penal Code and the Code of Criminal Proce-dure were resulted almost simultaneously. Despite the different nature (according to the author of the quoted view) of the condition of dual criminality in extradition proceedings (or more broadly: in the law on international cooperation in criminal matters), arguments of systemic na-ture cannot be left unnoticed, in particular, that the Polish courts, when interpreting the condi-tion of dual criminality in procedural law, often use the argumentation based on the criminal, material provisions, indicates the author of this view ${ }^{23}$.

\section{Concept of crime}

In the perspective of the criminality of an act committed abroad and its recognition as a crime therein, it is necessary to move within the scope and framework of the designate of the concept of crime in extenso, defined by the Polish legislator. It is impossible to accept - there is no basis for this - that the Polish legislator specifically in art. $111 \S 1$ C.C. using the term ,crime”: a) understands it and its overall legal framework in a different way than he does in the space of the Criminal Code, or b) that he entrusts the definition of what a crime is to the law of an ,alien". Ambivalent is naming of a ,crime” committed abroad (in the place of its perpetration), that is, whether it is called a crime, felony, misdemeanor, offense, violation, criminal act, punitive act, punishable act, bad deed, transgression, misdeed, delict, wrongdoing, maleficence, etc. In the context of art. $111 \S 1$ C.C., an act recognized as a ,crime” also by the law in force at the place of its commission (abroad), must also comply with all the conditions of crime specified in Polish law; it is a crime in concreto and not in abstracto. In a logical sense, if in a particular, concrete case, exists elements of the designate of the term ,crime”: a) belonging only to foreign law, b) belonging to both Polish law and foreign law, c) belonging only to Polish law. It is necessary to take account both: belonging to Polish law and foreign law (b]). Should therefore share the view, that the concept of criminality should be under-stood broadly, which means, that researching the fulfillment of criminality condition, it is not only necessary to refer to the content of a provision of the Polish criminal statute, which could corre-spond to the provision of foreign state law, but also to the current, applicable interpretation, relating to the scope of application of this provision in the system of Polish law. It is necessary to assess the entire factual situation, in order to determine, whether it is possible on the bases of the Polish crimi-nal law, presenting the perpetrator an allegation of making the $\mathrm{act}^{24}$.

\section{Foreign statute - statute of committing}

A number of doubts will also be given to the question of the ,statute" in force at the place where the act was committed, in the context of art. $111 \S 1$ C.C. In this perspective, it is claimed that: a) the concept of a statute in force at the place of committing an act should be understood broad-ly, and the condition of criminality is also fulfilled, when the act is recognized at the place of committing as a crime by customary law, if the custom is a recognized source of criminal law there ${ }^{25}$,

b) the concept of the law should be understood broadly, it includes all kinds of sources of criminal law in force at the place where the prohibition act is committed, therefore, it is also about the

\footnotetext{
${ }^{23}$ And more A. Falkiewicz, Glosa do wyroku s.okręg. z dnia 6 lutego 2014 r., VIII Ka 790/13 [Commentary to the judgement of the District Court of February 6, 2014, VIII Ka 790/13], Prokuratura $i$ Prawo, No. 12/2017 [last viewed: May 24, 2019] https://sip.lex.pl/\#/publication/386210729.

${ }^{24}$ Thesis to the decision of Supreme Court of November 22, 2011, sign. IV KK 267/11, LEX No. 1095846.

${ }^{25}$ M. Kulik, op. cit., commentary to the art. 111, thesis 3; M. Kulik gives the source of this view: A. Wąsek (in:) O. Górniok (et. al.), Kodeks karny. Komentarz [Criminal Code. Commentary], tom I (Gdansk:
} 
custom or courts case law in the common law system ${ }^{26}$;

c) the term „law" should be interpreted broadly, including not only statutory provisions sensu stricto, but all kinds of sources of criminal law in force at the place where the prohibition act was committed; also regarding courts case law in the common law system ${ }^{27}$. In a foreign criminal law (for instance in the common law system), not only the statute is a source of criminal law. It is also the case law (courts case law) and custom (in the criminal law of Islam, considered there as sacred book - for example - Koran). It seems that - having this comparative aspect in mind - it will be acceptable to adopt a functional interpretation of the term statute in art. 111 $\S 1$ C.C. (similarly in art. $111 \S 2$ C.C.) $)^{28}$;

d) by the "statute" is in force at the place of its commission, should be understood all kinds of sources of universally binding law in the territory of a specific state, even taking into account court case law (court ruling). It does not matter whether the provisions in the foreign law system have statutory rank or the rank of basic legal acts ${ }^{29}$.

\section{Conclusion}

The condition of art. $111 \S 1$ C.C., is similar to the principle of nullum crimen sine lege, that's mean it gives the perpetrator of an prohibited act the chance to avoid a criminal sanction. The condition of criminality of an act is fulfilled, when a specific act could be classified as a crime in the perspective of all the provisions in force in a specific country (dual criminality in concreto) ${ }^{30}$. The term „statute" (in force at the place where the act was committed) in the perspective of art. 111 C.C. should be refer to its material sense; in this sense, the statute is a legal act, containing abstract and general norms and influencing on the sphere of individual rights and freedoms, publicly an-nounced by this one who takes care for the community, which is a regulation-indication (ordinatio) of a reason (mind), given for the common $\operatorname{good}^{31}$. It should be pointed out, that such a statute may hypothetically include within its scope (for instance on the basis of reference) also provisions of other types of legal acts, as well as provisions of a religious nature or religion origin, customary norms, courts case law.

The Polish legislator in art. $111 \S 1$ of the Criminal Code specifies that the condition for liabil-ity for an act committed abroad is the recognition of such an act as a crime, also by the law in force at the place where it was committed. If this condition is not fulfilled, the Polish criminal law applies to a Polish citizen and the foreigner in cases where the principle of absolute application of the Polish penal statute (referred to in in Article 112 of the Criminal Code) or the principle of universal repres-sion (referred to in Article 113 of the Criminal Code) applies. Consideration should be given to the circumstances which exclude unlawfulness, culpability (guilt); the whole factual situation should be taken into account in order to answer the question: is it possible - in the perspective of Polish crimi-nal law - to bring on the perpetrator of a prohibited act, the allegation of committing a concrete crime?

Keywords: Polish criminal law, crime committed abroad, foreign crime, dual criminality (in Polish and in foreign criminal law).

Submitted 12.05.2021

Wydawnictwo ARCHE, 2005), p. 784. Similarly G. Łabuda, op. cit., commentary to the art. 111, thesis 2.

${ }^{26} \mathrm{~K}$. Banasik, op. cit.

${ }^{27}$ J. Raglewski (in:) W. Wróbel, A. Zoll (red.) Kodeks karny. Część ogólna. Tom I. Część II. Komentarz do art. 53-116 [Criminal Code. General section. Vol. I. Part II. Commentary to the art. 53-116] (Wolters Kluwer Polska, 2018) [last viewed: May 3, 2019], https://sip.lex.pl/\#/commentary/587713013/510453, commentary to the art. 111, thesis 5. The question of the criminality of an act committed abroad is assessed in concreto, what means, that this act would fulfill the signs of crime under foreign law. It must also be a culpable and punishable act under that law (Identically: J. Raglewski, as above); P. Hofmański (in:) Kodeks karny. Komentarz [Criminal Code. Commentary] (Wydawnictwo Prawnicze LexisNexis, 2006) [last viewed: May 15, 2019], https://sip.lex.pl/\#/ commentary/587560932/466840, com-mentary to the art. 111, thesis 3. Similarly A. Sakowicz, op. cit., p. 1330.

${ }^{28}$ A. Wąsek, op. cit., p. 784 and 785; compare K. Wiak, op. cit., p. 726 and 727.

${ }^{29}$ P. Czarnecki, P. Hofmański, op. cit., commentary to the art. 111, thesis 3.

${ }^{30}$ L. Gardocki, Zarys prawa karnego międzynarodowego [Outline of international criminal law] (Warszawa: Państwowe Wydawnictwo Naukowe, 1985), p. 156.

${ }^{31}$ Tomasz z Akwinu, Prawo [Law] (in:) Suma teologiczna [Summa Theologica] (Londyn: Veritas, 1986) [last viewed: September 2, 2019], http://zwola-old.karmelicibosi.pl/p/z/formacja/summa/summa_13.pdf, p. 8. 